\title{
Margaret McCartney: For Scotland, the real winner is democracy
}

\author{
Margaret McCartney general practitioner, Glasgow
}

A sleepless night. I was on the sleeper train-that little bit of Scotland that comes nightly to London-unable to stay away from my Twitter feed, my heart pounding. The votes are now in. Scotland is staying, the Union is unbroken, and even though I voted No (it's complicated), I feel tearfully disappointed for the passionate Yes supporters, sitting in George Square in central Glasgow, gutted (as we say).

The real winner is democracy. The voter turnout was $85 \%$, compared with just over 50\% at the Scottish election in 2011. On buses, in queues, in shops, pubs, and coffee houses, the conversation has been all about the referendum. The past few days have been electric: tartan, saltires, posters in the windows of ordinary homes ("yes I said yes I will Yes"*).

Sixteen year olds, and some younger, have been talking about the issues with knowledge, care, and fervour. Meetings in town halls, community centres, and schools have shown a standard of debate far higher than the rammy we saw on television. Everyone has opinions. And, although some frankly strange coalitions have lined up to take the same view on the referendum, social justice has become the vocal demand from people on both sides of the debate.

It's no longer weird to talk about such things-it has become normal. Instead, the argument is about how best,

administratively, to achieve this justice. As for the Health and Social Care Act, people know about, and are talking about, the privatisation of the NHS. People on the streets are worried about the private contracts still in Scotland, and they know about the threat to the NHS across borders. In a properly working democracy we are now wide awake, and the politicians are being told, straight back, that citizens don't want to see the NHS go to tender for private contracts.

It's clear to me that 16 and 17 year olds should be invited to vote, and if we give people visions and options that inspire or tell us about real life, then we will become involved. Imagine: bottom-up politics. Who knows? Now, it may actually happen. The next task is to harness the energy and enthusiasm of the people who invested themselves in this campaign. The Yes voters lost by only a little, and they need their vision represented - for fair welfare, in particular.

There was huge anger, both at the "Yes" and the "No" meetings I went to, that ill people are treated with suspicion and hostility when they need assistance through benefits. And the shamefully wide differences in life expectancy across Glasgow are a motivation to all of us to narrow the income gap and tackle social inequalities.

Get us all on board and we are stronger, and I believe that we have more in common than separates us. I'm proud to be a Scot; I hope that, in staying, we can make Britain better.

Competing interests: I have read and understood the BMJ policy on declaration of interests and declare the following interests: I'm an NHS GP partner, with income partly dependent on Quality and Outcomes Framework (QOF) points. I'm a part time undergraduate tutor at the University of Glasgow. l've written a book and earned from broadcast and written freelance journalism. I'm an unpaid patron of Healthwatch. I make a monthly donation to Keep Our NHS Public. I'm a member of Medact. I'm occasionally paid for time, travel, and accommodation to give talks or have locum fees paid to allow me to give talks but never for any drug or public relations company. I was elected to the national council of the Royal College of General Practitioners in 2013.

${ }^{*}$ Referencing James Joyce's Ulysses.

Provenance and peer review: Commissioned; not externally peer reviewed.

Follow Margaret McCartney on Twitter, @mgtmccartney

Cite this as: BMJ 2014;349:95773

๑ BMJ Publishing Group Ltd 2014 